PRZEGLĄD NAUK HISTORYCZNYCH 2019, R. XVIII, NR 1

http://dx.doi.org/10.18778/1644-857X.18.01.03

\title{
Radom jako miejsce obrad sejmików i lokalnych zjazdów szlacheckich w drugiej polowie XVIII wieku
}

Streszczenie. Osiemnastowieczny Radom, choć był miastem stosunkowo niewielkim, do 1763 r. był miejscem obrad Trybunału Skarbowego Koronnego, przez co odgrywał istotna rolę w życiu szlachty. Panowanie Stanisława Augusta odebrało Radomiowi status „miasta trybunalskiego”, na szczeblu lokalnym wzmocniło jednak jego rolę poprzez ustanowienie lokalnych sejmików. Od XVI w. województwo sandomierskie, którego częścią był powiat radomski, obradowało wspólnie w Opatowie, sejm konwokacyjny, wprowadzając odrębny sąd ziemski dla powiatów chęcińskiego, opoczyńskiego i radomskiego, miejscem elekcji jego urzędników naznaczył jednak Radom. W 1768 r. podjęto też próbę ustanowienia w Radomiu sejmików deputackich. Reforma z 1791 r. przewidywała $z$ kolei w mieście obrady sejmików poselskich $z$ jednoczesnym zmniejszeniem okręgu sejmików elekcyjnych do samego powiatu radomskiego. Nowe prawo obowiazywało jednak zaledwie kilka miesięcy. W analizowanym okresie w Radomiu odbywały się także zjazdy nieprzewidziane prawem, a związane $z$ konfederacją barska (1769), konfederacją targowicka (1792) i insurekcja kościuszkowska (1794). Ogółem na przestrzeni lat 1765-1794 w Radomiu zebrało się sześć sejmików i trzy zjazdy.

Słowa kluczowe: Radom, powiat radomski, sejmiki, samorząd lokalny, szlachta.

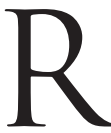
adom u schyłku istnienia Rzeczypospolitej był dość typowym królewskim miasteczkiem o niewielkim potencjale gospodarczym i demograficznym, którego rozwój przestrzenny dość skutecznie ograniczały średniowieczne mury obronne. W 1765 r.

\footnotetext{
*E-mail: kozdrachmariusz@wp.pl.
} 
odnotowano w mieście 137 domów (łącznie $z$ przedmieściami) ${ }^{1}$, przeważnie drewnianych ${ }^{2}$, które zamieszkiwało około 700 osób ${ }^{3}$.

$Z$ punktu widzenia stanu uprzywilejowanego Radom był jednak przede wszystkim siedzibą urzędów i instytucji, które stale bądź okresowo funkcjonowały $\mathrm{w}$ mieście. Ogół szlachty niewatpliwie postrzegał Radom przez pryzmat Trybunału Skarbowego, który do 1763 r. zbierał się tu corocznie, gromadząc senatorów i deputatów $z$ całej Korony ${ }^{4}$. Dla okolicznej szlachty stolica powiatu radomskiego była zaś siedzibą starosty i kancelarii grodzkiej. Okres panowania Stanisława Augusta przyniósł wzmocnienie roli miasta jako lokalnego ośrodka politycznego i sądowo-administracyjnego przez ulokowanie tu sądu ziemskiego, a zwłaszcza sejmików będących - według Jolanty Choińskiej-Miki - elementem konstytuującym społeczność lokalną ${ }^{5}$. Celem podejmowanych tu rozważań jest ukazanie sejmików i zjazdów szlacheckich obradujących w Rado-

${ }^{1}$ Lustracja województwa sandomierskiego, powiatów radomskiego, opoczyńskiego, chęcińskiego i ziemi stężyckiej Roku 1765, Archiwum Główne Akt Dawnych w Warszawie [dalej: AGAD], Metryka Koronna, dz. XVIII, sygn. 36, s. 3. Dla porównania: w połowie XVI w. doliczono się w mieście 116 domów, nie licząc zwolnionych $\mathrm{z}$ podatku. Lustracja województwa sandomierskiego 1564-1565, wyd. W. Ochmański, Wrocław-Warszawa-Kraków 1963, s. 162.

${ }^{2}$ W 1790 r. odnotowano w Radomiu zaledwie osiem domów murowanych. Pracownia Słownika Historyczno-Geograficznego Małopolski w Średniowieczu Instytut Historii PAN w Krakowie [dalej: PSHG IH PAN Kraków], Kartoteka słownika województwa sandomierskiego w dobie Sejmu Wielkiego [dalej: Kartoteka WS], hasło: Radom Nowy.

${ }^{3}$ Por. Radom i miasta królewskie powiatu radomskiego $w$ dobie Sejmu Czteroletniego, [w:] Radom i region radomski $w$ dobie szlacheckiej Rzeczypospolitej, t. V (Pogranicze Mazowsza i Małopolski), red. Z. Guldon, S. Zieliński, Radom 1999, s. 5; Spis ludności dyecezyi krakowskiej z r. 1787, wyd. J. Kleczyński, „Archiwum Komisyi Historycznej Akademii Umiejętności w Krakowie” 1894, t. VII, s. 324.

${ }^{4}$ D. Kupisz, Wprowadzenie, [w:] L. Babiński, Trybunał Skarbowy Radomski (Organizacja. Postepowania). Na podstawie ksiag Trybunału z lat 1614-1658, J. Rafacz, Trybunat Skarbowy Koronny, red. D. Kupisz, Radom 2013, s. 3-5. O sile zakorzenienia w powszechnej świadomości funkcjonowania Trybunału w Radomiu świadczyć może to, że jeszcze w czasie obrad Sejmu Wielkiego posłujący $z$ województwa czernihowskiego gen. Kajetan Kurdwanowski zgłosił w izbie propozycję przeniesienia Komisji Wojskowej do Radomia. Dyaryusz seymu ordynaryinego pod zwiazkiem konfederacyi generalney Oboyga Narodow w Warszawie rozpoczętego Roku Pańskiego 1788, t. I, cz. 2, Warszawa 1790, s. 413; J. Gacki, Radom i jego kościoły do końca XVIII wieku, [w:] Radom i region radomski $w$ dobie szlacheckiej Rzeczypospolitej, t. IV, oprac. S. Zieliński, Radom 1999, s. 198.

${ }^{5}$ J. Choińs ka-Mika, Między społeczeństwem szlacheckim a władza. Problemy komunikacji społeczności lokalne - władza w epoce Jana Kazimierza, Warszawa 2002, s. 9. 
miu w okresie 1765-1790, co wpisuje się w nurt podobnych badań nad samorządem szlacheckim XVI-XVIII w. ${ }^{6}$

Województwo sandomierskie, którego częścią był powiat radomski, zgodnie $z$ prawem i sięgająca XVI stulecia tradycja, obradowało wspólnie (wszystkimi powiatami) w Opatowie ${ }^{7}$. Wyjątkiem był sejmik elekcyjny w Stężycy, na którym szlachta z zawiślańskiej części województwa obierała urzędników reaktywowanego w połowie XVI w. sądu ziemskiego stężyckiego ${ }^{8}$. Tamtejsi ziemianie regularnie domagali się też ustanowienia - wzorem księstwa oświęcimsko-zatorskiego - odrębnego sejmiku dla swej ziemi ${ }^{9}$. Podobnych aspiracji nie przejawiali obywatele lewobrzeżnej części województwa, choć powszechnie odczuwany był problem dominacji w obradach szlachty $z$ bliższych Opatowa i bogatszych powiatów południowych ${ }^{10}$. Do rozbudzenia tendencji autonomicznych nie przyczyniły się nawet okazowania, gromadzace cyklicznie szlachtę powiatowa. Wprawdzie znane sa przypadki, gdy zebrani na popisie ziemianie, pod wpływem naglących problemów, uchwalali laudum, a w 1711 r. w Radomiu zastrzeżono sobie nawet w uchwale prawo organizowania takich zjazdów („sejmików”) w przyszłości ${ }^{11}$, były to jednak przypadki odosobnione. Nie doprowadziły też do faktycznego powstania sejmików partykularnych ${ }^{12}$. Wpłynąć na to mógł fakt, że - zdaniem Wojciecha Szczygielskiego - „sejmik opatowski po-

${ }^{6}$ Por. J. Gerlach, Grudziadz miejscem obrad sejmiku generalnego Prus Królewskich (1454-1772), „Rocznik Grudziądzki” 1963, t. III, s. 7-33; W. Fili p czak, Bolimów jako miejsce obrad sejmików województwa rawskiego $w$ XVII-XVIII wieku, „Rocznik Łódzki” 2016, t. LXIV, s. 11-35; M. Zwierzykowski, E. Tacka, Miejsca obrad sejmików województw Wielkopolski właściwej od XVI do XVIII wie$k u$, „Res Historica” 2016, t. XLII, s. 75-100.

7 Z. Trawicka, Sejmik województwa sandomierskiego w latach 1572-1696, Kielce 1985, s. 17-18.

8 Urzędnicy województwa sandomierskiego XVI-XVIII wieku. Spisy, red. A. Gasiorowski, Kórnik 1993, s. 7, 136. Por. Laudum sejmiku ziemi stężyckiej w Stężycy 1 IX 1589 r., Biblioteka PAU-PAN w Krakowie [dalej: BPAU-PAN Kraków], rkps 8338, k. $56-57 \mathrm{v}$.

9 Z. Trawicka, op. cit., s. 22.

${ }^{10}$ Stąd m.in. propozycje, by kandydatów do Trybunału Koronnego losować po jednym $z$ powiatów sandomierskich i radomskich. Ibidem, s. 22, 38.

${ }_{11}$ Laudum zjazdu szlachty powiatu radomskiego z 1711 roku, oprac. D. Kupisz, [w:] Z dziejów administracji $w$ Małopolsce $w$ XVI-XX wieku, red. D. Kupisz, Radom 2003, s. 115-118. Z. Trawicka, op. cit., s. 22, 269 wzmiankuje także „sejmik białaczowski”, na którym ok. 1661 r. miała się zebrać szlachta powiatu radomskiego lub powiatów radomskich.

12 Por. Laudum zjazdu szlachty..., s. 116, przyp. 8. 
siadał historycznie ukształtowaną wysoką rangę moralno-polityczną sejmiku poselskiego dla całego województwa sandomierskiego, którą trudno było współczesnym kwestionować"13.

Pierwszy (od ustanowienia zjazdów elekcyjnych w Stężycy w XVI w.) wyłom w scentralizowanym charakterze sejmiku województwa sandomierskiego przyniosły decyzje podjęte na sejmie konwokacyjnym z 1764 r. Ustanawiając odrębny sąd ziemski dla trzech tzw. powiatów radomskich, przewidziano wówczas, że elekcje kandydatów do tych funkcji sądowych będa się odbywały na zjazdach w Radomiu ${ }^{14}$. W sensie formalnym (uniwersały wydawał wojewoda sandomierski ${ }^{15}$ ) i symbolicznym (w uchwałach posługiwano się określeniem „laudum palatinatus sandomiriensis districtuum radomiensis"16) autonomia nowego sejmiku była ograniczona. Odmienny - względem opatowskiego - zasięg terytorialny zjazdu (powiaty radomski, opoczyński i chęciński) pozwala jednak kwalifikować go jako byt odrębny ${ }^{17}$.

Nieliczne znane uchwały sejmiku radomskiego wskazuja, że zjazdy w Radomiu ograniczały się do samego aktu elekcji. Nie podejmowano na nich żadnych spraw o charakterze gospodarczym ani politycznym, tak w wymiarze lokalnym, jak ogólnokrajowym ${ }^{18}$.

${ }^{13}$ W. Szczygielski, Referendum trzeciomajowe. Sejmiki lutowe 1792 roku, Łódź 1994, s. 47.

14 Volumina legum [dalej: Vol. leg.], t. VII, wyd. J. Ohryzko, Petersburg 1860, s. 36. Powołanie odrębnego sądu ziemskiego dla trzech północnych powiatów województwa sandomierskiego było jednym $z$ postulatów sejmiku opatowskiego na sejm konwokacyjny. Co jednak ciekawe, sejmikujący proponowali, aby „elekcyja [...] ad mentem dawnych niegdyś sejmików w mieście Skrzynnie [...] naznaczona była". Sejmiki w Skrzynnie zbierały się przez krótki czas za Zygmunta I Starego, ale zniesiono je już w 1519 r. Instrukcja poselska sejmiku województwa sandomierskiego w Opatowie z 6 II 1764 r., BPAU-PAN Kraków, rkps 8341, s. 591-592; Vol. leg., t. I, s. 176. Por. W. Pałucki, Granice i podziały polityczno-administracyjne, [w:] Atlas Historyczny Polski. Województwo sandomierskie w drugiej połowie XVI wieku, cz. 2 (Komentarz. Indeksy), red. W. Pałucki, Warszawa 1993, s. 49; W. Kri g g e is en, Sejmiki Rzeczypospolitej szlacheckiej w XVII i XVIII wieku, Warszawa 1991, s. 33.

15 Vol. leg., t. VII, s. 36.

16 Laudum sejmiku ziemi radomskiej w Radomiu 23 X 1775 r., Biblioteka Czartoryskich w Krakowie [dalej: BCz.], rkps 930, s. 347.

17 Por. A. Lityński, Z problematyki klasyfikacji sejmików ziemskich, „Prace Naukowe Uniwersytetu Śląskiego w Katowicach” 1969, nr 5, Prace Prawnicze, nr 1, s. 101-103.

18 Laudum sejmiku ziemi radomskiej z 23 X 1775 r. w Radomiu, BCz., rkps 930, s. 347-349; Laudum sejmiku ziemi radomskiej z 17 XII 1781 r. w Radomiu, AGAD, tzw. Metryka Litewska [dalej: ML], dz. IX, sygn. 93, s. 28-30. 
Sejmik zbierał się też tylko doraźnie, w razie powstania wakansu w obsadzie sądu ziemskiego. Inauguracyjne posiedzenie, na którym miano wyłonić kandydatów do pierwszego kompletu sądowego, wyznaczono na 4 lutego 1765 r. ${ }^{19}$ Do reform Sejmu Wielkiego zbierał się jeszcze czterokrotnie: w latach $1775-1776$ oraz w 1781 r. $^{20}$

W kierunku wzmocnienia rangi Radomia jako miasta sejmikowego prowadziły reformy sejmu nadzwyczajnego 1767/1768 r. Uchwalone wówczas zmiany w organizacji Trybunału Koronnego pociagnęły za sobą reorganizację sieci sejmików deputackich. Zgodnie $z$ nowym prawem województwo sandomierskie miało odtą wybierać nie dwóch, a jednego deputata na zjazdach „w Opatowie i Radomiu alternata" 21 . Mało precyzyjne zapisy ustawy nie rozstrzygają, czy sejmiki miały mieć charakter partykularny, czy też w obu miejscach miała się gromadzić szlachta całego województwa ${ }^{22}$. Niestety rozwój wypadków nie pozwolił na przetestowanie tego prawa w praktyce.

Wobec działań konfederacji barskiej przepis pozostawał przez kilka lat martwy, a decyzja kolejnego sejmu (1773-1775) „radomskie” sejmiki deputackie zostały zniesione. Wprawdzie przyjęte wówczas przepisy dotyczace Trybunału Koronnego stanowiły, że obiór depu-

${ }^{19}$ Laudum tego zjazdu nie jest znane. Termin pierwszego sejmiku wyznaczyła konstytucja sejmu koronacyjnego. Nominacje dla całej trójki sędziowskiej pochodzą z 1 marca 1765 r., Vol. leg., t. VII, s. 152; Urzędnicy województwa..., s. 74-76.

${ }^{20}$ Objęcie kasztelanii połanieckiej przez dotychczasowego sędziego radomskiego Andrzeja Święcickiego (15 II 1775 r.) rozpoczęło „karuzelę awansów” na urzędach radomskiego sądu ziemskiego, skutkiem czego w latach 1775-1776 sejmik elekcyjny zbierał się w Radomiu aż trzy razy. W 1782 r. szlachta nurska wyłoniła na jednym sejmiku kandydatów na sędziego i podsędka (spodziewając się awansu dotychczasowego podsędka na sędziego), co wzbudziło kontrowersje. Por. W. Fili p czak, Elekcje ziemskich urzędników sadowych w czasach Rady Nieustajacej, [w:] Wokół wolnych elekcji w państwie polsko-litewskim XVI-XVIII wie$k u$. O znaczeniu idei wyboru - między prawami a obowiazkami, red. M. Markiewicz, D. Rolnik, F. Wolański, Katowice 2016, s. 593. Ostatni sejmik w Radomiu, zwołany po śmierci Antoniego Skarbek-Radońskiego, odbył się 17 XII 1781 r. W. Filipczak, Ziemskie urzędy sadowe $w$ życiu politycznym województwa sandomierskiego $w$ latach 1777-1783, „Przegląd Nauk Historycznych” 2016, R. XV, nr 2, s. 204.

21 Vol. leg., t. VII, s. 318.

${ }^{22}$ Za ustanowieniem zjazdów w Radomiu (alternata) stać mogła chęć zmniejszenia odczuwalnej w Opatowie dominacji na obradach bogatszej szlachty powiatów południowych. Wszak uboższym ziemianom z północy (np. z ziemi stężyckiej czy powiatu opoczyńskiego) łatwiej byłoby dostać się do Radomia. Por. Z. Trawicka, op. cit., s. 38. Zwraca jednak uwagę, że w ustawie nie użyto określenia „alternata ziem", który wprost wskazywałby na konieczność wyboru naprzemiennie przedstawiciela powiatów „sandomierskich” i „radomskich”. 
tatów odbywać ma się „sposobem w konstytucyi roku tysięcznego siedemsetnego sześćdziesiątego ósmego, tak co do porządku elekcyi, jako ziem alternat przepisanym", miejscem zebrań województwa sandomierskiego naznaczano jednak wyłącznie Opatów ${ }^{23}$.

Pewne wattpliwości budzi miejsce i tryb odbywania sejmików gospodarskich (boni ordinis). Według Wacława Szczygielskiego w 1779 r. sejmik gospodarski zebrał się w Radomiu, pod przewodnictwem starosty radomskiego Aleksandra Potkańskiego ${ }^{24}$. Zgodnie $z$ prawem zjazdy tego typu szlachta miała jednak odprawiać dzień po zakończeniu sejmiku deputackiego ${ }^{25}$. Te ostatnie zaś, po nieudanej - jak wiadomo - próbie wprowadzenia alternaty $z$ Radomiem, odbywały się wyłącznie w Opatowie. Tam też, pod marszałkiem Janem Nepomucenem Dunin-Karwickim, regentowiczem koronnym ${ }^{26}$, szlachta obierała deputata 15 lipca 1779 r. ${ }^{27}$ Mało realny wydaje się wobec tego wzmiankowany przez W. Szczygielskiego zjazd w Radomiu, choć laudum sejmiku gospodarskiego $z$ tego roku (ani $z$ Radomia, ani $z$ Opatowa) nie udało się odnaleźć.

Należy pamiętać, że wskutek odebrania sejmikom kompetencji podatkowych (konstytucjami sejmów z lat 1766-1767/1768) częsta praktyka było odbywanie sejmików gospodarskich tego samego dnia co deputackich, a nawet omawianie problemów lokalnych bezpośrednio na sejmikach deputackich ${ }^{28}$. Podobna tendencje obserwuje się również w województwie sandomierskim. Wprawdzie

${ }^{23}$ Vol. leg., t. VIII, s. 106.

${ }^{24}$ W. Szczygiels ki, Potkański Aleksander h. Brochwicz (zm. po 1803), [w:] Polski słownik biograficzny [dalej: PSB], t. XXVII, Wrocław-Warszawa-Kraków 1982, s. 720. Informację o sejmiku gospodarskim w Radomiu w roku 1779 powtarza m.in. D. Ku pis z, Rody szlacheckie ziemi radomskiej, Radom 2009, s. 190.

25 Vol. leg., t. VII, s. 31.

${ }^{26}$ Syn Józefa Dunin-Karwickiego regenta kancelarii koronnej. A. Boniecki, Herbarz polski, t. IX, Warszawa 1906, s. 315-316.

${ }^{27}$ Laudum sejmiku województwa sandomierskiego w Opatowie 15 VII 1779 r., BPAU-PAN Kraków, rkps 8341, s. 993-995.

28 A. Lityński, Samorzą szlachecki w Polsce XVII-XVIII wieku, „Kwartalnik Historyczny" 1992, R. XCIX, z. 4, s. 28, 30; id e m, O reformach sejmikowania w latach 1764 1793, „Czasopismo Prawno-Historyczne” 1985, t. XXXVII, z. 2, s. 268; i d e m, Sejmiki województwa płockiego przed i w czasie Sejmu Czteroletniego. Z badań nad organizacja i funkcjonowaniem, [w:] W dwusetna rocznice wolnego Sejmu. Ludzie - państwo prawo czasów Sejmu Czteroletniego, red. idem, Katowice 1988, s. 80; W. Fili pczak, Sejmiki województwa płockiego 1780-1786, „Przegląd Nauk Historycznych" 2009, R. VIII, nr 2, s. 53-54; idem, Życie sejmikowe prowincji wielkopolskiej w latach 1780-1786, Łódź 2012, s. 493. 
na obraz mogą tu rzutować luki w materiale źródłowym ${ }^{29}$, jednak w świetle znanych uchwał sejmikowych stwierdzić można, że zdecydowana większość zjazdów gospodarskich odbyła się w tym samym terminie co deputackie. Dnia 15 lipca 1780 r. szlachta zgromadzona w Opatowie na obiór deputata wprost stwierdziła: „lubo prawo sejmiki gospodarskie nazajutrz determinuje, że jednak obszernej materyi do rozporzadzenia nie mamy przeto teraz, nieodstępnie pod tąż samą powaga J[aśnie] W[ielmożne]go zagajającego i tymże Wielmożnym marszałkiem [...] stanowiemy [...]"30. Sprawy elekcji do Trybunału Koronnego łaczono $z$ kwestiami lokalnymi na jednym zjeździe również w latach 1774-1775, 1787 i $1790^{31}$. W roku 1777 , 1783 i 1785 spisano odrębne lauda zjazdów gospodarskich, odbyły się one jednak tego samego dnia (15 VII) i pod tym samym marszałkiem, co deputackie ${ }^{32}$. Właściwie znany jest zaledwie jeden przypadek zupełnie odrębnego sejmiku gospodarskiego $-z 22$ sierpnia $1780 \mathrm{rr}^{33} \mathrm{Za}$ każdym razem jednak były to zjazdy szlachty całego województwa sandomierskiego. W okresie tym nie spotyka się natomiast wzmianek o sejmikach partykularnych poszczególnych powiatów.

Przedstawione fakty każą się dokładniej przyjrzeć kwestii rzekomych obrad sejmiku gospodarskiego w Radomiu w 1779 r. Wacław Szczygielski, który wprowadził tę informację do obiegu naukowego, powoływał się na drukowaną mowę Aleksandra Potkańskiego „W sprawie "wyciagania intrat"” 34 . Niewatpliwie chodzi tu o druk „Mowa J.W. Jmci P. Potkańskiego Starosty Radomskiego, Prezydu-

29 Nie sa znane uchwały sejmików deputackich $z$ lat 1767, 1778, 1782, 1786, 1788, 1789. Por. Deputaci Trybunału Koronnego 1578-1794. Spis, cz. 5 (1751-1794), oprac. J. Ternes, Warszawa 2017, s. 186, 225, 248, 271, 282, 289.

${ }^{30}$ Laudum sejmiku województwa sandomierskiego w Opatowie 15 VII 1780 r., BPAU-PAN Kraków, rkps 8341, s. 1002-1003.

${ }^{31}$ Laudum sejmiku województwa sandomierskiego w Opatowie 15 VII 1774 r., ibidem, s. 845-846; Laudum sejmiku województwa sandomierskiego w Opatowie 15 VII 1775 r., ibidem, s. 853; Laudum sejmiku województwa sandomierskiego w Opatowie 15 VII 1787 r., ibidem, s. 1146; Laudum sejmiku województwa sandomierskiego w Opatowie 15 VII 1790 r., ibidem, s. 1212-1213.

${ }^{32}$ Laudum sejmiku województwa sandomierskiego w Opatowie 15 VII 1777 r., ibidem, s. 921-922, Laudum sejmiku województwa sandomierskiego w Opatowie 15 VII 1783 r., ibidem, s. 1097; Laudum sejmiku województwa sandomierskiego w Opatowie 22 VIII 1785 r., ibidem, s. 1125.

${ }^{33}$ Laudum sejmiku województwa sandomierskiego w Opatowie 22 VIII 1780 r., ibidem, s. 1037 i n.

${ }^{34}$ W. Szczygiels ki, Potkański Aleksander..., s. 720. 
iącego w Kommissyi powiatowey do wyciagania intrat przy zagajeniu tey Kommissyi”, wydany - według „Bibliografii” Estreicherów - w 1779 r. ${ }^{35}$ Nie udało się odnaleźć żadnego egzemplarza tej broszury $^{36}$. Sam jej tytuł skłania jednak do zakwestionowania przyjmowanej datacji druku, wskazuje bowiem na działalność powołanych 30 maja 1789 r., w związu $z$ uchwalaniem tzw. ofiary dziesiątego grosza, komisji „dla wyegzaminowania ogólnych intrat $z$ dóbr ziemskich" ${ }^{37}$. Aleksander Potkański znalazł się wśród 15 komisarzy powołanych dla powiatu radomskiego ${ }^{38}$, a sama komisja, której - jako najwyższy urzędnik w składzie - „prezydował”39, rozpoczęła prace 1 lipca 1789 r. ${ }^{40}$

Pozostając przy problemie datacji mowy Potkańskiego, należy wspomnieć o jeszcze jednej wzmiance źródłowej. Pod dniem 6 września 1778 r. w metrykach parafii Nowego Radomia odnotowany został podstoli wiślicki Wojciech Święcicki - „sędzia obecnej komisji" [podkr. - M.K.] ${ }^{41}$. Zagadkowy zapis zdaje się potwierdzać istnienie około 1778/1779 r. w Radomiu kolegialnego ciała o uprawnieniach sądowo-administracyjnych. Wpis ten można by wiązać $z$ Komisją Dobrego Porządku wyznaczoną dla miast królewskich województwa sandomierskiego 26 sierpnia $1778 \mathrm{r}^{42}$, w składzie której znalazł się m.in. Wojciech Święcicki. Komisarze rozpoczęli jednak pracę od Sandomierza, gdzie zresztą zjechali dopiero w 1784 r. ${ }^{43}$ Komisja dla Radomia i Zwolenia została powo-

${ }^{35}$ K. Es treich er, Bibliografia polska, cz. 3, t. XIV (XXV), Kraków 1913, s. 128.

36 Jedyny egzemplarz znany Estreicherowi przechowywany był w Bibliotece Ordynacji Krasińskich w Warszawie, której zbiory uległy zagładzie w czasie drugiej wojny światowej.

37 Vol. leg., t. IX, s. 77.

38 Ibidem, s. 78.

39 J. Gacki, op. cit., s. 211.

40 Protokót ofiary dziesiatego i dwudziestego grosza powiatu radomskiego, wyd. Z. Guldon, S. Zieliński, [w:] Radom i region radomski w dobie szlacheckiej Rzeczypospolitej, t. II (Historia społeczno-religijna okresu wczesnonowożytnego), red. Z. Guldon, S. Zieliński, Radom 1996, s. 227.

${ }^{41}$ Księgi Metrykalne Kościołów Radomskich, seria A (Metryki chrztów), t. X (Kościół św. Jana Chrzciciela 1772-1795), red. D. Kupisz, Radom 2012, s. 73 (błędnie $z$ tytułem stolnika).

${ }^{42}$ Ordynacja dobrego porzadku dla Ryczywołu z 1788 roku, oprac. Z. Guldon, J. Wijaczka, „Wieś Radomska” 1993, t. IV, s. 41.

${ }_{43}$ M. Bulińs ki, Monografia Sandomierza, Warszawa 1879, s. 142-143; A. H araty m, Święcicki Wojciech h. Jastrzębiec (zm. między 1803 a 1806), [w:] PSB, t. LI, Warszawa-Kraków 2017, s. 480 (autor datuje powołanie Komisji na 14 IX 1778 r.). 
łana zaś 27 listopada 1787 r. ${ }^{44}$ Ostatecznie wydaje się, że - jak w przypadku mowy Potkańskiego - doszło do omyłki wydawców. W oryginalnej metryce Święcicki został określony mianem iudex comitio pro tunc ${ }^{45}$, co wiązać można $z$ pełnieniem przezeń funkcji sędziego sejmowego (wyznaczony na sejmie 1776 r.) ${ }^{46}$.

Reasumując, dostępne źródła nie potwierdzają odbywania w latach 1764-1790 w Radomiu sejmików gospodarskich. Zgromadzenia tego typu łączono najczęściej $z$ deputackimi i jako takie odprawiano w gronie szlachty wszystkich powiatów w Opatowie.

Rewolucję w geografii sejmikowej województwa sandomierskiego przyniosły ustalenia Sejmu Wielkiego. Przyjęta 24 października 1791 r. ustawa „Rozkład województw, ziem i powiatów, z oznaczeniem miast, a w nich miejsc konstytucyjnych dla sejmików w prowincjach Koronnych i Wielkiego Księstwa Litewskiego" ${ }^{47}$ zmierzała bowiem w kierunku daleko posuniętej decentralizacji szlacheckiego samorządu ${ }^{48}$. Zgodnie $z$ nowymi przepisami w województwie sandomierskim powszechny charakter (sejmiku generalnego) utrzymał jedynie sejmik deputacki w Opatowie. Elekcje posłów i urzędników lokalnych miały zaś odbywać się na czterech zjazdach partykularnych. Wśród nowych ośrodków sejmikowych znalazł się m.in. Radom jako miejsce zebrań szlachty powiatu radomskiego, a w przypadku sejmików przedsejmowych także ziemi stężyckiej (obie jednostki miały w Radomiu wyłaniać wspólnie dwóch posłów) ${ }^{49}$.

${ }^{44}$ J. Lu b oń s ki, Monografja historyczna miasta Radomia, Radom 1907, s. 31-32.

${ }^{45}$ Archiwum parafii św. Jana Chrzciciela w Radomiu, Księga metrykalna 1757-1781, s. 184.

46 Vol. leg., t. VIII, s. 541. W skład Sadu Sejmowego po reformach z lat 1773-1776 wchodziło - obok senatorów niezasiadających w Radzie Nieustającej - 30 posłów wybieranych na sejmie na dwa lata. Sąd obradował w składzie co najmniej 24 osób na sześciotygodniowych kadencjach (1 X, 2 II, 1 VI). W przypadkach wyjątkowych (oskarżenia o zdradę i obrazę majestatu) także poza kadencjami, za rezolucją Rady Nieustającej. Ibidem, s. 82, 541-543; Z. Szczą s ka, Sad sejmowy w okresie rząów Rady Nieustajacej. Proces barona Juliusa, „Przegląd Historyczny” 1971, t. LXII, z. 3, s. 421, 426.

47 Vol. leg., t. IX, s. 326; A. Lityńs ki, Sejmiki ziemskie..., s. 131.

${ }^{48}$ W. Kriegseise n, op. cit., s. 265.

49 Pozostałe sejmiki miały się zjeżdżać w Opatowie (pow. sandomierski), Stopnicy (pow. wiślicki i pilzneński) i Opocznie (pow. opoczyński i chęciński). W Stężycy miał się zbierać sejmik elekcyjny ziemi stężyckiej (wyłącznie dla wyboru urzędników lokalnych). Chyba za omyłkę prawodawców należy natomiast uznać uwzględnienie w sieci sejmików powiatu pilzneńskiego odpadłego od Rzeczypospolitej już w pierwszym rozbiorze. Vol. leg., t. IX, s. 327. 
Istotne zmiany w geografii sejmikowej przyniosła, przyjęta także na Sejmie Wielkim (19 I 1792), „Deklaracyja dla prowincjów Koronnych względem porządnego odbycia sejmików w dniu 14 lutego 1792 roku przypadajacych"50. Zdaniem W. Szczygielskiego jej postanowienia znosiły wspomnianą ustawę z $1791 \mathrm{r}$., wprowadzając „zupełnie nowy podział sejmików zarówno dla Prowincji Wielkopolskiej, jak i Prowincji Małopolskiej"51. W przypadku województwa sandomierskiego nie widać jednak większych różnic w strukturze sejmikowej52. Na zjazd lutowy miały się zjechać do Opatowa wszystkie powiaty, co pozostawało w zgodzie z ustawa z $1791 \mathrm{r}$., był to bowiem sejmik deputacki (czyli generalny). Elekcje sędziów ziemiańskich i pisarza „Deklaracyja” przewidywała zaś „po rozjechaniu się obywatelów", zatem na sejmikach partykularnych (tak jak w „Rozkładzie ziem”). Układ tych ostatnich także odpowiadał siatce ustalonej w $1791 \mathrm{r}^{53} \mathrm{~W}$ ustawie $z 19$ stycznia $1792 \mathrm{r}$. nie wspominano o wyborze posłów, widocznie jednak sejmiki przedsejmowe miały się odbywać według przepisów z $1791 \mathrm{r}$. Tak przynajmniej interpretowała zapisy konstytucji ówczesna szlachta.

W memoriale złożonym przez szlachtę ziemi stężyckiej po sejmikach lutowych 1792 r. utyskiwano na to, że ziemia stężycka „przyłączona jest do opatowskiego sejmiku na wybór deputata [...] a do radomskiego sejmiku na wybór posła”. Wskazywano na trudy przeprawy przez Wisłę („doświadczyli już nieraz tego obywatele topiąc się, i tą ostatnia razą $z$ wielkim hazardem ledwie mogliśmy jednego przeprawić $z$ księga ziemiańska na sejmik do Opatowa”), choć nie ukrywano również obaw o zdominowanie przez ziemian pozostałych powiatów. Rozwiązaniem postulowanym przez szlachtę ziemi stężyckiej miało być przyznanie większej autonomii sejmikowi w Stężycy. „Niechaj nam wolno będzie - apelowano w memoriale - nadal na sejmiku naszym obrać posła sposobem Księstwa Mazowieckiego, [...] obywatele powiatu radomskiego [...] niechajże obieraja jednego u siebie, a my drugiego u siebie" ${ }^{4}$. Żadnych zmian w obowiąujacym prawie nie zdążył już jednak wprowadzić Sejm Wielki.

\footnotetext{
50 Ibidem, s. 395; A. Lityń ski, Sejmiki ziemskie..., s. 131.

${ }^{51}$ W. Szczygiels ki, Referendum trzeciomajowe..., s. 20, 22.

52 Vol. leg., t. IX, s. 395.

53 Pominięto jedynie, uwzględniony w „Rozkładzie województw i ziem...”, powiat pilzneński. Ibidem.

${ }^{54}$ Memoriał szlachty ziemi stężyckiej, b.m. i d., AGAD, Archiwum Sejmu Czteroletniego, sygn. $21, \mathrm{k} .74-74 \mathrm{v}$.
} 
Na mocy przepisów z lat 1791-1792 odbył się w Radomiu tylko sejmik elekcyjny (w celu wyłonienia składu sądu ziemiańskiego), który zgodnie $z$ przepisami konstytucji miał się zebrać dwa tygodnie po deputackim, a uchwała zjazdu opatowskiego z 14 lutego $1792 \mathrm{r}$. naznaczony został na 2 marca $^{55}$. Wiadomo, że szlachta zgromadzona w Radomiu obradowała cztery dni ${ }^{56}$, niestety uchwała tego zjazdu nie jest znana. Przewidziany prawem sejmik poselski (18 VIII 1792) $)^{57}$ w Radomiu już się nie odbył. Wraz ze zwycięstwem targowicy w lipcu 1792 r. ustawodawstwo Sejmu Czteroletniego zostało zniesione. Kolejne zjazdy - wyznaczone na 27 maja 1793 r. sejmiki przedsejmowe - odbyły się według przepisów sprzed $1791 \mathrm{r} .{ }^{58}$, tzn. całym województwem w Opatowie ${ }^{59}$.

Prawodawstwo ostatniego sejmu Rzeczypospolitej w odniesieniu do sejmików obficie czerpało z przepisów Sejmu Wielkiego ${ }^{60}$, w sposób zdecydowany zrywało jednak z zasadą decentralizacji. Po 1793 r. każde województwo miało się składać $z$ trzech ziem i obradować na wspólnym sejmiku. W przypadku województwa sandomierskiego na miejsce zjazdów szlachty wyznaczono kościół kolegiacki w Kielcach ${ }^{61}$.

Za panowania Stanisława Augusta szlachta zbierała się zatem w Radomiu na obrady sejmikowe zaledwie sześciokrotnie. W tym samym okresie w mieście odbyło się jednak też kilka zjazdów nieprzewidzianych prawem, na których okoliczni ziemianie, zwykle pod wpływem zagrożenia zewnętrznego, podejmowali decyzje o charakterze polityczno-administracyjnym dotyczące tej części województwa ${ }^{62}$.

${ }^{55}$ Laudum sejmiku województwa sandomierskiego w Opatowie z 14 II 1792 r., BPAU-PAN Kraków, rkps 8341, s. 128; W. Szczygielski, referendum trzeciomajowe..., s. 46, 192.

${ }^{56}$ A. Stadnicki do H. Kołłątaja, Wieniawa 8 III 1792, BPAU-PAN Kraków, rkps 197, k. 169.

57 Vol. leg., t. VII, s. 233.

58 A. Lityński, Sejmiki ziemskie..., s. 177-178.

59 „Korrespondent Kraiowy i Zagraniczny”, 4 VI 1793, nr 45, s. 905-906 (dodatek).

60 A. Lityński, Sejmiki ziemskie..., s. 181.

61 Vol. leg., t. X, s. 310.

${ }^{62} \mathrm{~W}$ zakreślonych ramach nie mieści się najgłośniejszy ze zjazdów odbytych w Radomiu - zawiazana w czerwcu 1767 r. konfederacja radomska. Związek nie miał charakteru lokalnego, jako konfederacja generalna zgromadził w mieście delegatów (konsyliarzy) konfederacji wojewódzkich. Szerzej o samej konfederacji por. B. Madejska, Konfederacja radomska 1767-1768 roku, „Biuletyn Kwartalny Radomskiego Towarzystwa Naukowego" 2003, t. XXXVIII, z. 3-4, passim; 
Do pierwszego ze wzmiankowanych zjazdów doszło w okresie konfederacji barskiej ${ }^{63}$, a jego bezpośrednim „inspiratorem” był Jan Szczawiński. Wiosna 1769 r., stojąc na czele konfederatów łęczyckich, zajął północno-zachodnią część województwa sandomierskiego, a 22 marca 1769 r. wkroczył do Radomia i zwołał do miasta okoliczna szlachtę ${ }^{64}$. Zebrani 31 marca ziemianie obradowali jak na sejmiku, wybierając marszałka i asesorów ${ }^{65}$. Po elekcji władz zjazdu zgromadzeni, zapewne nie mając wiadomości o utworzeniu kilka dni wcześniej związku wojewódzkiego w Pilźnie, a „wsparci [...] gotowością prześwietnego województwa łęczyckiego", zawiązali konfederację województwa sandomierskiego, powołując na jej marszałka kasztelana żarnowskiego Franciszka Ksawerego Korwin-Kochanowskiego ${ }^{66}$. Pod aktem podpisało się 178 osób, głównie $z$ terenów zajętych przez Szczawińskiego ${ }^{67}$. Radomski charakter zjazdu i konfederacji potwierdza też fakt, że konsyliarzy wybrano wyłącznie dla północnej części województwa - powiatów radomskiego, opoczyńskiego, chęcińskiego i ziemi stężyckiej68. Także $\mathrm{w}$ przypadku rotmistrzów powiatowych wstrzymano się $z$ nomina-

G.T. Lukowski, The szlachta and the confederacy of Radom, 1764-1767/8: A study of the Polish nobility, „Antemurale” 1977, t. XXI, passim.

${ }^{63}$ Szerzej o konfederacji barskiej na terenie powiatu radomskiego por. D. Kupisz, Konfederaci barscy i Kazimierz Pułaski $w$ regionie radomskim, [w:] Kazimierz Pułaski i jego czasy $w$ historii, literaturze, kulturze. W 270 rocznice urodzin, red. D. Kupisz, A. Pytlak, Radom-Warka 2016, s. 9-18.

${ }^{64},[. .$.$] nie tylko proszac, ale i grożąc [...]”, „Księga domowa” Leona i Hieroni-$ ma Kochanowskich (1763-1855), wyd. J.K. Kochanowski, „Przegląd Historyczny" 1916, t. XX, s. 182-183; H. Żerek-Kleszcz, Szczawiński Jan (Jan Chrzciciel) h. Prawdzic (po 1723-po 1795), [w:] PSB, t. XLVII, Warszawa-Kraków 2010, s. 200.

${ }^{65}$ Akt konfederacji województwa sandomierskiego w Radomiu z 31 III 1769 r., Lvìvska Nacionalna Naukova Bìblìoteka Ukraïni im. V. Stefanyka [dalej: LNNBU], f. 5, op. 1, sp. $1407 /$ II, s. 102-103.

${ }^{66}$ Ibidem, s. 99 i n.

${ }^{67}$ Wśród sygnatariuszy wskazać można ośmiu urzędników ziemskich radomskich, pięciu opoczyńskich, trzech sandomierskich i dwóch wiślickich (większość z nich dziedziczyła jednocześnie w Radomskiem). Ibidem, s. 113-117. Do samej liczby uczestników zjazdu należy podchodzić ostrożnie, ponieważ Leon Korwin-Kochanowski, podpisany pod aktem, wspominał, że do Radomia przybył dopiero 1 IV i wówczas zaprzysiagł konfederację. „Księga domowa”..., s. 183.

$68,[. .$.$] pominąwszy sandomirskie powiaty, z których aż tam wstapiwszy, kon-$ syliarze nominowani i wybrani będą [...]". Wyjątkiem był 1 konsyliarz wiślicki, którym mianowano obecnego w Radomiu łowczego wiślickiego Wojciecha Święcickiego. Akt konfederacji województwa sandomierskiego w Radomiu z 31 III 1769 r., LNNBU, f. 5, op. 1, sp. 1407 /II, s. 104. 
cjami dla południowych powiatów, pozostawiając prawo ich patentowania marszałkowi Kochanowskiemu ${ }^{69}$.

Radom ponownie stał się miejscem zjazdu lokalnej szlachty w okresie konfederacji targowickiej ${ }^{70}$. Wkrótce po przystapieniu króla do targowicy, 30 lipca 1792 r. w mieście zgromadziło się kilkudziesięciu okolicznych ziemian i pod przewodnictwem miejscowego starosty Aleksandra Potkańskiego zawiazało konfederację województwa sandomierskiego ${ }^{71}$. Podobnie jak w 1769 r. był to formalnie związek całego województwa, jeszcze wyraźniej niż poprzednio widać w nim jednak dominację szlachty radomskiej ${ }^{72}$. Dopiero na powtórzonym, na żądanie władz konfederacji generalnej, zjeździe w Radomiu z 23 sierpnia 1792 r. w większym stopniu uczestniczyli obywatele powiatu opoczyńskiego ${ }^{73}$.

Ostatni za panowania Stanisława Augusta zjazd w Radomiu odbył się w okresie insurekcji. Stacjonujace w regionie oddziały moskiewskie ${ }^{74}$ przez długi czas uniemożliwiały poderwanie województwa sandomierskiego, o co apelował Tadeusz Kościuszko75. Rozwój

69 Ibidem, s. 105-106.

70 Szerzej o konfederacji targowickiej w powiecie radomskim por. M. Kozdrach, Radomskie wobec Targowicy i Grodna (lipiec 1792 - marzec 1794), „Radomskie Studia Humanistyczne" 2017, t. IV, s. 25-42.

71 Akt konfederacji województwa sandomierskiego w Radomiu z 30 VII 1792 r., BPAU-PAN Kraków, rkps 8341, s. 1302.

${ }^{72}$ M. Kozdrach, op. cit., s. 26-29.

73 „Korrespondent Warszawski”, 30 VIII 1792, nr 52, s. 461-463; W. S moleński, Konfederacya targowicka, Kraków 1903, s. 292; M. Kozdrach, op. cit., s. 29-31.

${ }^{74}$ Por. B. Szyndle r, Powstanie kościuszkowskie 1794, Warszawa 1994, s. 64, 73-74; W. Tokarz, Marsz Madalińskiego, Warszawa 1926 (odbitka z „Przeglad Wiedzy Wojskowej” 1925, R. II) s. 51-52 (211-212); R. Ku bicki, Wojska i działania wojenne $w$ okolicy Opatowa od konfederacji barskiej do wojen napoleońskich, „Z dziejów Regionu i Miasta. Rocznik Oddziału PTH w Skarżysku-Kamiennej” 2010, R. I, s. 63-65; A. Kawale c, Ksiądz Franciszek Siarczyński. Życie i działalność, Wrocław-Warszawa-Kraków 2007, s. 47-48; A. J elo n ki ew i cz-C h ęć, Kozienice. Założenie Pałacowo-Ogrodowe, Kozienice 1999, s. 42-43; L. Łoboda, Kozienice od połowy XVII do końca XVIII wieku, [w:] Kozienice. Monografia miasta, red. S. Piątkowski, Kozienice 2004, s. 66-67, 92; J. J ad a ch, Kozienice w 1794 roku, „Ziemia Kozienicka” 1996, z. 5, s. 5-6.

${ }^{75}$ T. Kościuszko do L. Korwin-Kochanowskiego, Kraków 28 III 1794 r., cyt. za: B. Szynd1er, Tadeusz Kościuszko 1746-1817, Warszawa 1991, s. 190 (fotokopia listu); A. Wilkoszewski, Komisje Porzadkowe Koronne za powstania Kościuszkowskiego, „Przeglad Historyczny” 1929, t. XXVIII, nr 2, s. 4 (222); J. Kow e cki, Pospolite ruszenie $w$ insurekcji 1794, Warszawa 1963, s. 86-87, 146-147; T. Kor zo n, Wewnętrzne dzieje Polski za Stanisława Augusta (1764-1794), t. I, KrakówWarszawa 1897, s. 484. 
wypadków ${ }^{76}$, a zwłaszcza konieczność obrony przed grasującymi po okolicy żołdakami skłaniały jednak do organizacji samoobrony ${ }^{77}$.

Dnia 10 maja $1794 \mathrm{r}^{78} \mathrm{w}$ Radomiu zjechało się 431 przedstawicieli miejscowej szlachty i mieszczaństwa ${ }^{79}$, którzy - nieświadomi ukonstytuowania się sandomierskich władz powstańczych w Nowym Mieście Korczynie ${ }^{80}$ - zgłosili akces całego województwa do powstania („nie dzieląc się bynajmniej od ogółu województwa naszego") ${ }^{81}$. Doraźnie bezpieczeństwo zjazdu zapewniał oddział milicji powołany $z$ uzbrojonych w kosy chłopów przysłanych przez dziedziców Piastowa (kasztelan zawichojski Józef Sołtyk ${ }^{82}$ ) i Jedlińska (Wilhelm Krystian Jakobson ${ }^{83}$ ) oraz mieszczan radomskich

76 Dnia 29 IV do powstania przyłaczyła się ziemia łukowska, 30 IV - lubelska, a 1 V - czerska. A. Wilkos zewski, op. cit., s. 59 (277).

77 Por. U. Tarnowska, Wspomnienia damy polskiej z XVIII wieku, [w:] Archiwum Wróblewieckie, z. 1, Poznań 1869, s. 75. Motyw bezpieczeństwa regionu jako dominujący jawi się także w samym akcie miejscowej insurekcji: „[...] widząc oraz starsze $z$ rzędu powiaty województwa naszego rozłożonemi w kilku miejscach, a mianowicie między Opatowem, Sandomierzem i Kunowem, nieprzyjacielskiemi obozami obarczone, a przez to przystapienia do powstającej siły narodowej sposobności pozbawione, nie dzieląc się bynajmniej od ogółu województwa naszego [...]". Akt insurekcji województwa sandomierskiego w Radomiu 10 V 1794 r., LNNBU, f. 45 , op. 1 , sp. 675 , k. 15 .

78 „Gazeta Wolna Warszawska”, 24 V 1794, nr 9, s. nlb. podaje datę $11 \mathrm{~V} 1794 \mathrm{r}$.

79 A. Wilkoszewski, op. cit., s. 6 (224).

$80,[\ldots]$ widzac oraz starsze $z$ rzędu powiaty województwa naszego rozłożonemi w kilku miejscach [...] nieprzyjacielskiemi obozami obarczone, a przeto przystapienia do powstającej siły narodowej sposobności pozbawione [...]”. Akt insurekcji województwa sandomierskiego w Radomiu 10 V 1794 r., LNNBU, f. 45, op. 1, sp. 675 , k. 15-15v. Województwo sandomierskie złożyło akces do powstania 30 IV 1794 r. w Nowym Mieście Korczynie. We władzach tamtejszej Komisji Porządkowej zasiadł m.in. Leon Korwin-Kochanowski, który „prezydował” posiedzeniu 1 V. Muzeum Okręgowe im. Jacka Malczewskiego w Radomiu [dalej: MJM Radom], inw. H/1428/20/85, s. nlb.; A. Wilkoszewski, op. cit., s. 5 (223); J. Kowecki, op. cit., s. 147. Według Marii Czeppe przed Korczynem miał się odbyć zjazd w Dzikowie (22 IV), gdzie Wojciecha Odrową̇-Strasza obrano ziemiańskim generał-majorem. M. Cze p pe, Strasz (Odroważ Strasz) Wojciech (zm. 1821 lub 1822), [w:] PSB, t. XLIV, Warszawa-Kraków 2006, s. 215.

${ }^{81}$ Akt insurekcji województwa sandomierskiego w Radomiu 10 V 1794 r., LNNBU, f. 45, op. 1, sp. 675, k. 15-15v.

${ }^{82}$ PSHG IH PAN Kraków, Kartoteka WS, hasło: Piastów. O zaangażowaniu kasztelana zawichojskiego w powstanie kościuszkowskie nie wspomina M. Czeppe, Sottyk Józef h. własnego (zm. 1803), [w:] PSB, t. XL, Warszawa-Kraków 2010, s. 386.

${ }^{83}$ Warszawski przedsiębiorca, nobilitowany w roku 1790 (nobilitacja powtórzona na sejmie grodzieńskim). Około 1791 r. przejął od Andrzeja Lanckorońskiego klucz jedliński, który dziedziczył do 1804 r. A. Boniecki, op. cit., t. VIII, 
uzbrojonych w karabiny ${ }^{84}$. Pod ich osłona zgromadzeni wyłonili Komisję Porządkową ${ }^{85}$, jak również Sąd Kryminalny ${ }^{86}$.

Zjazdy szlacheckie $z$ lat 1769, 1792 i 1794, choć nieraz organizowane pod przymusem (bezpośrednim lub pośrednim), traktować należy jako przejaw zaangażowania szlachty powiatowej na szczeblu lokalnym. Wyłonione wówczas władze niejednokrotnie pozostawały w konflikcie $z$ organami samorząowymi południa województwa ${ }^{87}$, należy jednak zaznaczyć, że - podobnie jak w przypadku sejmików - formalnie podkreślano ich powszechny, wojewódzki charakter i nie przejawiano tendencji separatystycznych. Sejmiki i zjazdy radomskie postrzegano zatem jako część samorządu województwa sandomierskiego.

Kwestią nie do końca rozstrzygnięta pozostaje, w którym dokładnie miejscu Radomia zbierała się szlachta na obrady. W konstytucji z 1764 r., wprowadzającej sejmik elekcyjny radomski, nie wskazano żadnego konkretnego obiektu ${ }^{88}$. Uchwały zjazdów $z$ tego okresu także niczego nie wnosza, wzmiankując jedynie „miejsce obradom naszym przyzwoite” ${ }^{89}$ czy „miejsce $z$ prawa [wynikajace - M.K.]”90. Dopiero zapisy konstytucji z roku 1791, moca której wyznaczono miejsca obrad wszystkim sejmikom w Koronie i na Litwie, dla zjazdów szlachty radomskiej wskazywały kościół farny w Radomiu ${ }^{91}$.

s. 155-156; S. Cynarski, Dzieje rodu Lanckorońskich z Brzezia od XIV do XVIII wieku, Warszawa-Kraków 1996, s. 217.

${ }^{84}$ „Gazeta Wolna Warszawska”, 24 V 1794, nr 9, s. nlb.; K. Bauer, Wojsko koronne powstania kościuszkowskiego, Warszawa 1981, s. 70, 269; J. Kow ecki, op. cit., s. 158 .

85 „Gazeta Wolna Warszawska”, 24 V 1794, nr 9, s. nlb.; A. Wilkos zew ski, op. cit., s. 6 (224), 17 (235).

86 „Gazeta Wolna Warszawska”, 24 V 1794, nr 9, s. nlb.

87 Przykładowo w 1794 r., gdy sandomierska Komisja Porządkowa uchwaliła $20 \mathrm{~V}$ podatki zgodne $z$ uniwersałami centralnych władz powstańczych, wskazując przy tym na poborcę radomskiego Franciszka Odrowąż-Kietlińskiego, w Radomskiem $-z$ polecenia miejscowej Komisji - próbowano wybierać podatki uchwalone na Sejmie Wielkim. MJM Radom, inw. H/1431/85, s. nlb. Por. Akty powstania Kościuszki, wyd. S. Askenazy, W. Dzwonkowski, t. I, Kraków 1918, s. 74-75; A. Wilkoszewski, op. cit., s. 41 (259).

88 Vol. leg., t. VII, s. 36.

${ }^{89}$ Laudum sejmiku ziemi radomskiej w Radomiu z 23 X 1775 r., BCz., rkps 930 , s. 347.

90 Laudum sejmiku ziemi radomskiej w Radomiu z 17 XII 1781 r., AGAD, ML, dz. IX, sygn. 93, s. 28. W podobnym duchu utrzymane sa uchwały zjazdów $z$ lat 1769, 1792 i 1794.

${ }^{91}$ Vol. leg., t. IX, s. 327. Pewne wątpliwości budzić może konstytucyjny zapis o odbywaniu sejmików w Radomiu „w kościele farnym w rynku bedacym 
Prawdopodobne wydaje się, że nowe prawo jedynie sankcjonowało istniejacy stan rzeczy i sejmiki $z$ lat 1765-1790 także obradowały w miejscowym kościele św. Jana Chrzciciela. Potencjalnych obiektów, w których mogła się zbierać szlachta w Radomiu, było jednak kilka.

W 1767 r., jak wiadomo, konsyliarze konfederacji lokalnych zebrani w Radomiu zgromadzili się w ratuszu, gdzie doszło do podpisania aktu konfederacji generalnej ${ }^{92}$. Niewatpliwie siedziba władz miejskich była w stanie pomieścić większa liczbę ludzi ${ }^{93}$, w latach dziewięćdziesiątych odbywały się tu bowiem bale na cześć Konstytucji 3 maja $^{94}$. Brakuje jednak jakichkolwiek śladów, by po $1767 \mathrm{r}$. obiekt był wykorzystywany na potrzeby szlacheckich zjazdów.

$\mathrm{Na}$ zamek jako miejsce obrad sejmiku wskazywał z kolei Michał Modzelewski w swych zbeletryzowanych wspomnieniach ${ }^{95}$. Niestety autor, świetnie zorientowany - dzięki wspomnieniom i notatkom ojca, dziedziczącego podradomskie Bieniędzice szambelana Wincentego Modzelewskiego - w plotkach z życia wyższych sfer ${ }^{96}$, nie zawsze jest ścisły w zakresie faktografii. Stąd nie sposób opierać się wyłącznie na tej relacji. Tym bardziej że radomski zamek, siedziba sądu i urzędu grodzkiego, wskutek przebudowy $z$ lat osiemdziesią-

[podkr. - M.K.]". Przy radomskim rynku położone było kolegium pijarów z kościółkiem św. Marcina, a nie fara. Nieścisłość można chyba jednak uzasadnić nieznajomością topografii miasta przez redagujacych konstytucję.

${ }^{92}$ G.T. Lukows ki, op. cit., s. 158-159; B. Mad ejs ka, op. cit., s. 26; J. Kitow i c z, Pamiętniki czyli historia polska, oprac. P. Matuszewska, Warszawa 1791, s. 165.

93 Ostatnie badania archeologiczne pozostałości rozebranego w XIX w. ratusza wykazały, że budynek miał wymiary 20,8 x 10,6 m. Por. G. Barczyk, J. Marciniak-Barczyk, W. Marciniak, Najstarszy ratusz Nowego Miasta $w$ Radomiu $w$ świetle badań archeologiczno-architektonicznych, „Radomskie Studia Humanistyczne" 2015, t. II, s. 302-305.

94, „[...] magistrat [...] zaprosił całą kompaniją na ratusz [...]”, gdzie „[...] urzędnicy i ziemianie $z$ mieszczanami tańcowali wspólnie i bawili się”. "Gazeta Narodowa i Obca", 23 V 1792, nr 41, s. 246.

${ }^{95}$ M. Modzelew ski, „Wrażenia podróży po Radomskiem w 1876 r.”, Biblioteka Jagiellońska w Krakowie, rkps 5146, k. 84v.

96 Testament szlachcica Wincentego Modzelewskiego z 1827 roku, oprac. S. Zieliński, „Wieś Radomska” 1993, t. IV, s. 59-60; R. Kaleta, Oświeceni $i$ sentymentalni. Studia nad literatura $i$ życiem $w$ Polsce $w$ okresie trzech rozbiorów, Wrocław-Warszawa-Kraków 1971, s. 239, 260-261; M. Modzelewski, Wrażenia podróży po Radomskiem w 1876 roku, oprac. S. Zieliński, „Radomir. Kwartalnik Turystyczno-Krajoznawczy Zarządu Wojewódzkiego PTTK w Radomiu” 1989, nr 2, s. 48-49 (edycja obejmuje jedynie fragmenty cytowanych $z$ rękopisu wspomnień M. Modzelewskiego). 
tych XVIII w., został przystosowany na potrzeby kancelarii - duże sale podzielono na mniejsze pokoje, raczej niezdolne do przyjęcia ludniejszych zgromadzeń ${ }^{97}$.

Wprawdzie przykłady sejmików obradujących w zamkach czy ratuszach (a nawet karczmach) sa znane, wśród obiektów wykorzystywanych do tego celu, zwłaszcza na terenie Małopolski, zdecydowanie przeważały jednak kościoły ${ }^{98}$. Radom, choć niewielki, dysponował w pierwszej połowie XVIII w. sześcioma świątyniami ${ }^{99}$, $z$ czego połowa była murowana. Wśród nich znajdował się bernardyński kościół klasztorny św. Katarzyny, położony już za murami miejskimi (na Przedmieściu Lubelskim), który jako miejsce odbywania sejmików wskazywał Jan Luboński, a za nim inni autorzy ${ }^{100}$. Niewątpliwie świątynia cieszyła się prestiżem ówczesnej szlachty i pełniła pewne funkcje publiczne (np. nabożeństwa inaugurujące sesje Trybunału Skarbowego) ${ }^{101}$, opinia J. Lubońskiego mogła jednak opierać się na praktyce dziewiętnastowiecznej, kiedy faktycznie sejmiki zbierały się u radomskich bernardynów ${ }^{102}$.

$\mathrm{Na}$ potrzeby publiczne wykorzystywano także gmach radomskiego kolegium pijarów. Do roku 1763, w czasie obrad Trybunału Skarbowego, od zakonników wynajmowano część pomieszczeń na potrzeby pisarzy kwarcianych ${ }^{103}$. Kolegium dysponowało także większą salą, zdolna pomieścić liczniejszych gości rozmaitych uroczystości szlacheckich ${ }^{104}$, która równie dobrze mogła przyjąć

97 Lustracja województwa sandomierskiego 1789, cz. 2 (Powiat radomski), oprac. H. Madurowicz-Urbańska, Wrocław-Warszawa-Kraków 1967, s. 175.

98 W. Kriegseise n, op. cit., s. 71-73.

${ }_{99}$ D. Kupis z, Dzieje parafii św. Jana Chrzciciela $w$ Radomiu $w$ XIV-XVIII wieku, [w:] Kościót św. Jana Chrzciciela w Radomiu. Architektura-ludzie - wydarzenia, red. idem, Radom 2010, s. 18.

100 J. Luboński, op. cit., s. 195; J. Wiśniewski, Dekanat radomski, Radom 1911, s. 261; E. Orzechowska, Radomscy bernardyni $w$ dobie powstania styczniowego, Radom 2008, s. 17; A. Janicka, Kościół i klasztor bernardynów $w$ Radomiu od XV do XVIII $w$. Miejsce działalności społecznej i stały element krajobrazu miejskiego, „Acta Universitatis Lodziensis”, Folia Historica 85, 2010, s. 19.

101 D. Ku p is z, Nekropolie Radomia $w$ drugiej połowie XVIII wieku, „Kwartalnik Historii Kultury Materialnej" 2016, R. LXIV, nr 1, s. 56.

${ }^{102} \mathrm{~W}$ klasztorze bernardyńskim odbył się sejmik poselski powiatu radomskiego z 20 I 1820 r. J. Luboński, op. cit., s. 117-118.

103 J. Ku rkow ski, Kolegium i szkoła pijarów w Radomiu 1680-1795, [w:] Radom i region..., t. II, s. 88 .

104 Por. m.in. „Wiadomości Warszawskie”, 19 XII 1772, nr 102, s. nlb.; J. Wiśniewski, op. cit., s. 274. 
sejmikujących. Należy jednak mieć na względzie, że do połowy lat osiemdziesiątych gmach wciąż był w budowie ${ }^{105}$.

W Radomiu nie zachowały się niestety żadne materialne ślady po miejscach obrad, znane choćby $z$ kolegiaty opatowskiej ${ }^{106}$, lokalne sejmiki pozostaja jednak istotnym elementem dziedzictwa kulturowego regionu. $Z$ tego względu problem ten zasługuje na dalsze badania. Także w kontekście wpływu tradycji osiemnastowiecznych zjazdów i doświadczeń lokalnej społeczności na funkcjonowanie samorzadu na tych ziemiach w wieku XIX.

\section{Bibliografia}

\section{Ź RÓDEA REKOPIŚMIENNE}

Archiwum Główne Akt Dawnych w Warszawie [AGAD]

Metryka Koronna, dz. XVIII, sygn. 36.

tzw. Metryka Litewska [ML], dz. IX, sygn. 93.

Archiwum Sejmu Czteroletniego, sygn. 21.

Archiwum parafii św. Jana Chrzciciela w Radomiu

Księga metrykalna 1757-1781.

Biblioteka Czartoryskich w Krakowie [BCz.]

rkps 930.

Biblioteka Jagiellońska w Krakowie

rkps 5146.

Biblioteka PAU-PAN w Krakowie [BPAU-PAN Kraków] rkps $197,8338$.

Lvìvska Nacìonalna Naukova Bỉblìoteka Ukraïni im. V. Stefanyka [LNNBU]

f. 5, op. 1, sp. 1407/II.

f. 45 , op. 1 , sp. 675 .

Muzeum Okręgowe im. Jacka Malczewskiego w Radomiu [MJM Radom] inw. H/1428/20/85. inw. $\mathrm{H} / 1431 / 85$.

105 J. Kurkowski, op. cit., s. 91.

106 S.K. Kuczyńs ki, Polskie herby ziemskie. Geneza, treści, funkcje, Warszawa 1993 , s. 191-193. 
Pracownia Słownika Historyczno-Geograficznego Małopolski w Średniowieczu Instytut Historii PAN w Krakowie [PSHG IH PAN Kraków]

Kartoteka słownika województwa sandomierskiego w dobie Sejmu Wielkiego [Kartoteka WS].

\section{Ź RÓDEA DRUKOWANE}

Akty powstania Kościuszki, wyd. S. Askenazy, W. Dzwonkowski, t. I, Kraków 1918.

Dyaryusz seymu ordynaryinego pod zwiazkiem konfederacyi generalney Oboyga Narodow w Warszawie rozpoczętego Roku Pańskiego 1788, t. I, cz. 2, Warszawa 1790.

Kitowicz J., Pamiętniki czyli historia polska, oprac. P. Matuszewska, Warszawa 1971.

„Ksiega domowa” Leona i Hieronima Kochanowskich (1763-1855), wyd. J.K. Kochanowski, „Przegląd Historyczny” 1916, t. XX, s. 175-197.

Księgi Metrykalne Kościołów Radomskich, seria A (Metryki chrztów), t. X (Kościót św. Jana Chrzciciela 1772-1795), red. D. Kupisz, Radom 2012.

Laudum zjazdu szlachty powiatu radomskiego z 1711 roku, oprac. D. Kupisz, [w:] $Z$ dziejów administracji $w$ Małopolsce $w$ XVI-XX wieku, red. D. Kupisz, Radom 2003, s. 115-118.

Lustracja województwa sandomierskiego 1564-1565, wyd. W. Ochmański, Wrocław-Warszawa-Kraków 1963.

Lustracja województwa sandomierskiego 1789, cz. 2 (Powiat radomski), oprac. H. Madurowicz-Urbańska, Wrocław-Warszawa-Kraków 1967.

Modzelewski M., Wrażenia podróży po Radomskiem w 1876 roku, oprac. S. Zieliński, „Radomir. Kwartalnik Turystyczno-Krajoznawczy Zarządu Wojewódzkiego PTTK w Radomiu" 1989, nr 2, s. 25-52.

Ordynacja dobrego porzadku dla Ryczywołu z 1788 roku, oprac. Z. Guldon, J. Wijaczka, „Wieś Radomska” 1993, t. IV, s. 41-57.

Protokót ofiary dziesiatego i dwudziestego grosza powiatu radomskiego, wyd. Z. Guldon, S. Zieliński, [w:] Radom i region radomski $w$ dobie szlacheckiej Rzeczypospolitej, t. II (Historia społeczno-religijna okresu wczesnonowożytnego), red. Z. Guldon, S. Zieliński, Radom 1996, s. 225-261.

Spis ludności dyecezyi krakowskiej z r. 1787, wyd. J. Kleczyński, „Archiwum Komisyi Historycznej Akademii Umiejętności w Krakowie” 1894, t. VII, s. 269-478.

Tarnowska U., Wspomnienia damy polskiej z XVIII wieku, [w:] Archiwum Wróblewieckie, z. 1, Poznań 1869, s. 1-119.

Testament szlachcica Wincentego Modzelewskiego z 1827 roku, oprac. S. Zieliński, „Wieś Radomska” 1993, t. IV, s. 59-64.

Volumina legum, t. I-VIII, wyd. J. Ohryzko, Petersburg 1859-1860.

Volumina legum, t. IX, wyd. A. Bojarski, Z. Kniaziołucki, Kraków 1889.

Volumina legum, t. X, wyd. Z. Kaczmarczyk, Poznań 1952. 


\section{Prasa}

„Gazeta Wolna Warszawska”, 24 V 1794, nr 9.

"Gazeta Narodowa i Obca”, 23 V 1792, nr 41.

„Korrespondent Kraiowy i Zagraniczny”, 4 VI 1793, nr 45.

„Korrespondent Warszawski”, 30 VIII 1792, nr 52.

„Wiadomości Warszawskie”, 19 XII 1772, nr 102.

\section{OpRacowania}

Barczyk G., Marciniak-Barczyk J., Marciniak W., Najstarszy ratusz Nowego Miasta $w$ Radomiu $w$ świetle badań archeologiczno-architektonicznych, „Radomskie Studia Humanistyczne" 2015, t. II, s. 295-312.

Bauer K., Wojsko koronne powstania kościuszkowskiego, Warszawa 1981.

Boniecki A., Herbarz polski, t. VIII-IX, Warszawa 1905-1906.

Buliński M., Monografia Sandomierza, Warszawa 1879.

Choińska-Mika J., Między społeczeństwem szlacheckim a władzą. Problemy komunikacji społeczności lokalne - władza w epoce Jana Kazimierza, Warszawa 2002.

Cynarski S., Dzieje rodu Lanckorońskich z Brzezia od XIV do XVIII wieku, Warszawa -Kraków 1996.

Czeppe M., Sołtyk Józef h. własnego (zm. 1803), [w:] Polski słownik biograficzny, t. XL, Warszawa-Kraków 2001, s. 385-386.

Czeppe M., Strasz (Odroważ Strasz) Wojciech (zm. 1821 lub 1822), [w:] Polski słownik biograficzny, t. XLIV, Warszawa-Kraków 2006, s. 215-216.

Deputaci Trybunału Koronnego 1578-1794. Spis, cz. 5 (1751-1794), oprac. J. Ternes, Warszawa 2017.

Estreicher K., Bibliografia polska, cz. 3, t. XIV (XXV), Kraków 1913.

Filipczak W., Bolimów jako miejsce obrad sejmików województwa rawskiego w XVII-XVIII wieku, „Rocznik Łódzki” 2016, t. LXV, s. 11-35.

Filipczak W., Elekcje ziemskich urzędników sadowych w czasach Rady Nieustajacej, [w:] Wokół wolnych elekcji w państwie polsko-litewskim XVI-XVIII wieku. O znaczeniu idei wyboru - między prawami a obowiazkami, red. M. Markiewicz, D. Rolnik, F. Wolański, Katowice 2016, s. 582-597.

Filipczak W., Sejmiki województwa płockiego 1780-1786, „Przegląd Nauk Historycznych" 2009, R. VIII, nr 2, s. 23-62.

Filipczak W., Ziemskie urzędy sądowe $w$ życiu politycznym województwa sandomierskiego w latach 1777-1783, „Przegląd Nauk Historycznych” 2016, R. XV, nr 2, s. 191-214.

Filipczak W., Życie sejmikowe prowincji wielkopolskiej w latach 1780-1786, Łódź 2012.

Gacki J., Radom i jego kościoły do końca XVIII wieku, [w:] Radom i region radomski w dobie szlacheckiej Rzeczypospolitej, t. IV, oprac. S. Zieliński, Radom 1999.

Gerlach J., Grudziądz miejscem obrad sejmiku generalnego Prus Królewskich (1454-1772), „Rocznik Grudziądzki” 1963, t. III, s. 7-33. 
Guldon Z., Radom i miasta królewskie powiatu radomskiego $w$ dobie Sejmu Czteroletniego, [w:] Radom i region radomski $w$ dobie szlacheckiej Rzeczypospolitej, t. V (Pogranicze Mazowsza i Małopolski), red. Z. Guldon, S. Zieliński, Radom 1999, s. 5-15.

Haratym A., Święcicki Wojciech h. Jastrzębiec (zm. między 1803 a 1806), [w:] Polski słownik biograficzny, t. LI, Warszawa-Kraków 2017, s. 480-482.

Jadach J., Kozienice w 1794 roku, „Ziemia Kozienicka” 1996, z. 5, s. 3-11.

Janicka A., Kościół i klasztor bernardynów w Radomiu od XV do XVIII w. Miejsce działalności społecznej $i$ stały element krajobrazu miejskiego, „Acta Universitatis Lodziensis", Folia Historica" 85, 2010, s. 7-20.

Jelonkiewicz-Chęć A., Kozienice. Założenie Pałacowo-Ogrodowe, Kozienice 1999.

Kaleta R., Oświeceni $i$ sentymentalni. Studia nad literatura $i$ życiem $w$ Polsce w okresie trzech rozbiorów, Wrocław-Warszawa-Kraków 1971.

Kawalec A., Ksiąz Franciszek Siarczyński. Życie i działalność, Wrocław-Warszawa -Kraków 2007.

Korzon T., Wewnętrzne dzieje Polski za Stanisława Augusta (1764-1794), t. I, Kraków-Warszawa 1897.

Kowecki J., Pospolite ruszenie w insurekcji 1794, Warszawa 1963.

Kozdrach M., Radomskie wobec Targowicy i Grodna (lipiec 1792 - marzec 1794), „Radomskie Studia Humanistyczne” 2017, t. IV, s. 27-46.

Kriegseisen W., Sejmiki Rzeczypospolitej szlacheckiej w XVII i XVIII wieku, Warszawa 1991.

Kubicki R., Wojska i działania wojenne w okolicy Opatowa od konfederacji barskiej do wojen napoleońskich, „Z dziejów Regionu i Miasta. Rocznik Oddziału PTH w Skarżysku-Kamiennej” 2010, R. I, s. 49-73.

Kuczyński S.K., Polskie herby ziemskie. Geneza, treści, funkcje, Warszawa 1993.

Kupisz D., Dzieje parafii św. Jana Chrzciciela w Radomiu w XIV-XVIII wieku, [w:] Kościół św. Jana Chrzciciela w Radomiu. Architektura - ludzie - wydarzenia, Radom 2010, s. 13-60.

Kupisz D., Konfederaci barscy i Kazimierz Pułaski $w$ regionie radomskim, [w:] Kazimierz Pułaski i jego czasy $w$ historii, literaturze, kulturze. W 270 rocznice urodzin, red. D. Kupisz, A. Pytlak, Radom-Warka 2016, s. 9-20.

Kupisz D., Nekropolie Radomia w drugiej połowie XVIII wieku, „Kwartalnik Historii Kultury Materialnej” 2016, R. LXIV, nr 1, s. 35-58.

Kupisz D., Rody szlacheckie ziemi radomskiej, Radom 2009.

Kupisz D., Wprowadzenie, [w:] L. Babiński, Trybunał Skarbowy Radomski (Organizacja. Postepowania). Na podstawie ksiag Trybunaku z lat 1614-1658, J. Rafacz, Trybunał Skarbowy Koronny, red. D. Kupisz, Radom 2013, s. 3-10.

Kurkowski J., Kolegium i szkoła pijarów w Radomiu 1680-1795, [w:] Radom i region radomski $w$ dobie szlacheckiej Rzeczypospolitej, t. II (Historia społeczno-religijna okresu wczesnonowożytnego), red. Z. Guldon, S. Zieliński, Radom 1996, s. 83-112.

Lityński A., O reformach sejmikowania w latach 1764-1793, „Czasopismo Prawno-Historyczne" 1985, t. XXXVII, z. 2, s. 257-272. 
Lityński A., Samorzą szlachecki $w$ Polsce XVII-XVIII wieku, „Kwartalnik Historyczny" 1992, R. XCIX, z. 4, s. 17-34.

Lityński A., Sejmiki województwa płockiego przed i w czasie Sejmu Czteroletniego. $Z$ badan nad organizacja i funkcjonowaniem, [w:] $W$ dwusetna rocznice wolnego Sejmu. Ludzie - państwo prawo czasów Sejmu Czteroletniego, red. A. Lityński, Katowice 1988, s. 76-108.

Lityński A., Z problematyki klasyfikacji sejmików ziemskich, „Prace Naukowe Uniwersytetu Śląskiego w Katowicach” 1969, nr 5, Prace Prawnicze, nr 1, s. 89-105.

Luboński J., Monografja historyczna miasta Radomia, Radom 1907.

Łoboda L., Kozienice od połowy XVII do końca XVIII wieku, [w:] Kozienice. Monografia miasta, red. S. Piątkowski, Kozienice 2004, s. 53-93.

Eukowski G.T., The szlachta and the confederacy of Radom, 1764-1767/ 8: A study of the Polish nobility, „Antemurale” 1977, t. XXI.

Madejska B., Konfederacja radomska 1767-1768 roku, „Biuletyn Kwartalny Radomskiego Towarzystwa Naukowego” 2003, t. XXXVIII, z. 3-4.

Orzechowska E., Radomscy bernardyni w dobie powstania styczniowego, Radom 2008.

Pałucki W., Granice i podziały polityczno-administracyjne, [w:] Atlas Historyczny Polski. Województwo sandomierskie $w$ drugiej połowie XVI wieku, cz. 2 (Komentarz. Indeksy), red. W. Pałucki, Warszawa 1993, s. 31-49.

Smoleński W., Konfederacya targowicka, Kraków 1903.

Szczaska Z., Są sejmowy w okresie rząów Rady Nieustajacej. Proces barona Juliusa, „Przegląd Historyczny” 1971, t. LXII, z. 3, s. 421-436.

Szczygielski W[acław], Potkański Aleksander h. Brochwicz (zm. po 1803), [w:] Polski słownik biograficzny, t. XXVII, Wrocław-Warszawa-Kraków 1983, s. 720-721.

Szczygielski W[ojciech], Referendum trzeciomajowe. Sejmiki lutowe 1792 roku, Łódź 1994.

Szyndler B., Powstanie kościuszkowskie 1794, Warszawa 1994.

Szyndler B., Tadeusz Kościuszko 1746-1817, Warszawa 1991.

Tokarz W., Marsz Madalińskiego, Warszawa 1926 (odbitka z „Przegląd Wiedzy Wojskowej" 1925, R. II).

Trawicka Z., Sejmik województwa sandomierskiego w latach 1572-1696, Kielce 1985.

Urzędnicy województwa sandomierskiego XVI-XVIII wieku. Spisy, red. A. Gąsiorowski, Kórnik 1993.

Wilkoszewski A., Komisje Porzadkowe Koronne za powstania Kościuszkowskiego, „Przegląd Historyczny” 1929, t. XXVIII, nr 2, s. 1-68 (219-286).

Wiśniewski J., Dekanat radomski, Radom 1911.

Zwierzykowski M., Tacka E., Miejsca obrad sejmików województw Wielkopolski właściwej od XVI do XVIII wieku, „Res Historica” 2016, t. XLII, s. 75-100.

Żerek-Kleszcz H., Szczawiński Jan (Jan Chrzciciel) h. Prawdzic (po 1723-po 1795), [w:] Polski słownik biograficzny, t. XLVII, Warszawa-Kraków 2010, s. 199-202. 
Mariusz Kozdrach

\section{Radom as a place of debates of sejmiks and local gentry congresses in the second half of the $18^{\text {th }}$ century}

Radom in the $18^{\text {th }}$ century was a small town, but untill 1763 it was the seat of the
Crown Treasury Tribunal, therefore it played an important role for the nobility.
Stanisław August Poniatowski's reign took away from Radom a "tribunal city"
status, however in the local level it strenghtened the town's role by establishing local
dietines in it. Since the $16^{\text {th }}$ century Sandomierz Voivodship, part of which was
the Radom District, confered together in Opatów. Convocation Diet, establishing
separate land court for the Checiny, Opoczno and Radom Distriucts, pointed
Radom as a place of the judicial officials' elections. In 1768 an attempt to establish
there deputy dietines was also taken. The 1791 reform intended in Radom envoy
dietines and reducted the elective dietines constituency to the Radom District itsef.
New law regulations were however in force for a few months only. In the examined
period Radom was also a place of assemblies not expressed in the law, resulting
from the events of the Confederacy of Bar (1769), Confederacy of Targowica (1792)
and the Kosiciuszko Uprising (1794). In general, Radom was a place of six dietines'
sessions and three assemblies during the $1765-1794$ period.

Keywords: Radom, Radom District, dietines, local self-governance, nobility. 